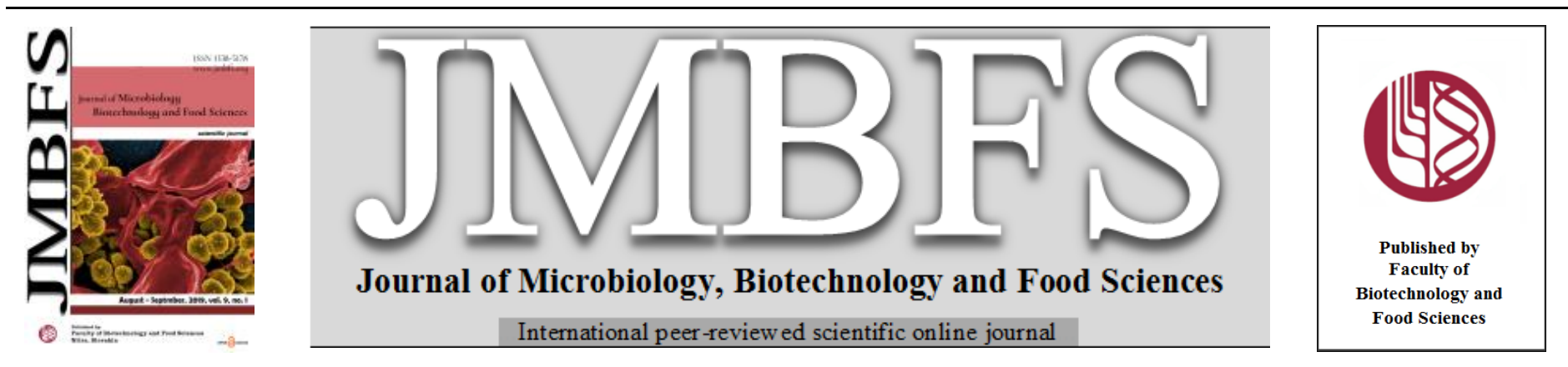

\title{
EXOGENOUS CYTOKININS APPLICATION INDUCES CHANGES IN STOMATAL AND GLANDULAR TRICHOMES PARAMETERS IN ROSEMARY PLANTS REGENERATED IN VITRO
}

\author{
Valbona Sota $*^{1}$, Sara Themeli ${ }^{1}$,Zhaneta Zekaj ${ }^{1}$,Efigjeni Kongjika ${ }^{2}$ \\ Address(es): Dr. Valbona Sota, \\ ${ }^{1}$ Department of Biotechnology, Faculty of Natural Sciences, University of Tirana, Bul. Zog I, Nr. 25/1, Tel. +355 4 2229590, Albania. \\ ${ }^{2}$ Academy of Sciences of Albania, Section of of Natural and Technical Sciences, Tel. +35542250368, Albania.
}

*Corresponding author: valbona.sota@ fshn.edu.al

doi: 10.15414/jmbfs.2019.9.1.25-28

\section{ARTICLE INFO}

Received 21. 1.2019

Revised 22. 2. 2019

Accepted 25. 2. 2019

Published 1. 8. 2019

Regular article

OPEN $\partial_{\text {AcCESS }}$

\begin{abstract}
Rosemary (Rosmarinus officinalis L.) is a native Mediterranean herb, used to typically prevent oxidation of fats and oils in foods and cosmetics. Rosemary represents an effective source of natural antioxidants with analgesic, diuretic, digestive and anti-inflammatory effects. This study is carried out to properly evaluate if exogenous cytokinin applications typically led to hyperhydration symptoms or any histological variability in stomatal density, stomatal distribution, glandular trichomes density and size of leaf epidermis. The colloidal technique was used for observation and measurement of leaf epidermis characters. The plantlets during in vitro culture were developed on MS media and two different PGRs ratios (BAP) / auxin (NAA) were tested: (i) $1 \mathrm{mg} \mathrm{l}^{-1} / 0.1 \mathrm{mg} \mathrm{l}^{-1}$ (ii) $2 \mathrm{mg} \mathrm{l}^{-1} / 0.1 \mathrm{mg} \mathrm{l}^{-1}$. In vitro leaves of both categories were taken for analyses 4 weeks after the first subculture and were compared with in vivo ones. The study showed that in vivo plantlets have hypostomatic leaves, meanwhile, in vitro plantlets of both categories consist of amphistomatic leaves. In all cases, there are observed anisocytic stomata. In vitro leaves have a higher stomatal density, value which is increased in higher concentrations of BAP and thus transpiration rates are affected. In vitro specimens show about 3 times higher trichomes density in comparison with in vivo ones, but their diameter is about 2 times lower. Glandular trichomes size and density are affected by BAP concentration in nutrient media. These results convincingly show that in vitro culture can be used successfully to improve secondary metabolites production by intentionally altering the growing physical and chemical conditions.
\end{abstract}

Keywords: rosemary, in vitro propagation, cytokinins, glandular trichomes

\section{INTRODUCTION}

Rosemary (Rosmarinus officinalis L.) is a native Mediterranean herb, used to prevent oxidation of fats and oils in foods and cosmetics. Rosemary represents an effective source of natural antioxidants with analgesic, diuretic, digestive and anti-inflammatory effects (Vallverdú-Queralt et $\boldsymbol{a l}$., 2014). Presently, the increasing demand for secondary metabolites has intensified the practical application of in vitro culture methods to increase the amount of these products in micropropagated plants under controlled environmental conditions. With great interest is finding a suitable micropropagation protocol, especially in the ratio of growth regulators, to enable high productivity. In such cases, there would be variations between in vivo and in vitro plantlets about the density of trichomes and secondary metabolic production. In this case, these might be constructive variations as they help to get the most productive plant lines (Jain, 2001; Gaspar et al., 2002).

Various culture conditions as the use of sealed vessels to prevent microbial infection and of the artificial nutrient media, the reduced intensity of light, etc. are factors that lead to the formation of plantlets with altered morphology, physiology and anatomy in comparison with in vivo plants. The differences refer to the shape of the leaf, cuticle structures, density and morphology of trichomes, distribution and function of the foliage, formation of the calcium oxalate crystals, etc. (Hazarika, 2006; Roberts et al., 1994; Soukup et al., 2004). Many of these changes may be responsive to stress caused by in vitro culture conditions as a result of which the first symptoms of hyperhydration occur. Such changes are considered as adaptations to the different external conditions during in vitro propagation (Kevers et al., 2004).

The aim of this research is to develop an in vitro propagation protocol to improve secondary metabolites production by modifying PGRs ratio in the nutrient media. Epidermal characters (stomata and glandular trichomes) of in vivo and in vitro plantlets of Rosemary L are evaluated and compared to test if exogenous cytokinin concentrations led to any morphological and histological variability, especially in glandular trichomes density and diameter.

\section{MATERIAL AND METHODS}

\section{Plant material and in vitro conditions}

The mature Rosemary plants were carefully collected during March from Dajti Mountain, Tirana, Albania. For in vitro culture, after surface sterilization, the shoot tips were cultured on MS media (Murashige and Skoog, 1962). Two different ratios of BAP / NAA were tested: (MS I) $1 \mathrm{mg} \mathrm{l}^{-1} / 0.1 \mathrm{mg} \mathrm{l}^{-1}$ and (MS II) $2 \mathrm{mg} \mathrm{l}^{-1} / 0.1 \mathrm{mg} \mathrm{l}^{-1}$. At least 20 replicates were used for each treatment and both treatments were repeated 3 times. The media was supplemented with sucrose $3 \%$ and agar-agar $0.55 \%$. pH value was adjusted at 5.5 before autoclaving. The cultures were maintained under $16 \mathrm{~h}$ light and $8 \mathrm{~h}$ darkness. The nutrient medium for each treatment contained the same hormonal combination during inoculation and subculture stage. In vitro leaves were taken for analyses 4 weeks after the first subculture.

\section{Epidermal characters evaluation}

For the comparative assessment between in vivo and in vitro plants, density of stomata and glandular trichomes on the upper leaf epidermis was evaluated. Regarding stomata's distribution, evaluation was made for both leaves surfaces. Samples were obtained via the colloidal technique which enables observation of stomata and glandular trichomes impressions in the slide utilizing an optical microscope. For each variant are analyzed at least 5 leaves with five microscopic fields each of them. For microscopic measurement was taken the third or the fourth leaf from the top. The measurements of stomata and glandular trichomes for in vivo samples were realized using a 10x magnification, meanwhile for in vitro ones a 40x magnification. Photomicrographs of the micrometer objective $(10 \mu \mathrm{m})$ in $10 \mathrm{x}$ and $40 \mathrm{x}$ were used for the calibration of microscopic fields via Optika Vision 3.4 program. The calibration was realized by calculating the diameter of the microscopic field in $10 \mathrm{x}$ and in $40 \mathrm{x}$, respectively $1867 \mu \mathrm{m}$ and $450 \mu \mathrm{m}$. After the counting of stomata and glandular trichomes, their 
density $/ \mathrm{mm}^{2}$ was calculated. Terminologies of stomatal complex types used in this research are those of Dilcher (1974) and Wilkinson (1979).

\section{Statistical analyses}

Results were analyzed by Student's Test and Analyses of Variance $(\mathrm{P}<0.05)$ All data, presented as means associated with the standard error, are carefully evaluated by computer using the statistical evaluation program JMP 7.0.

\section{RESULTS AND DISCUSSION}

Stomata distribution, type and density of in vivo plants and in vitro treatments

In vivo and in vitro leaves were examined for stomatal distribution on the two sides of leaf epidermis. From microscopic evaluation, it could be observed that in vivo plants are hypostomatic because stomatal complexes are present only in the lower leaf epidermis. In vitro leaves, in both treatments, result to be amphistomatic because stomatal complexes are present in the upper and the lower epidermis. As it can be seen from figure $1 \mathrm{a}, \mathrm{b}$, the type of stomatal complex is anisocytic (with three accompanying cells surrounding the guard cells)
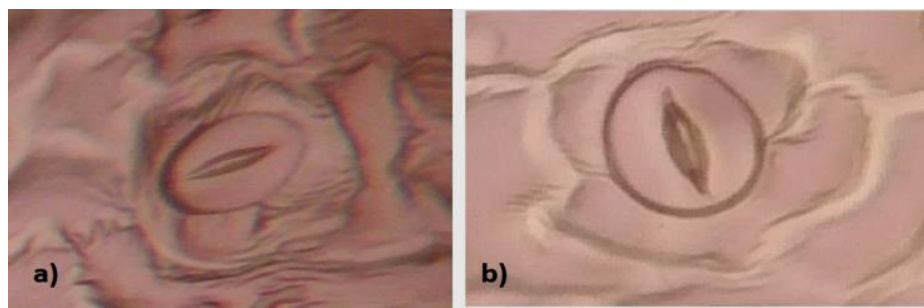

Figure 1 Anisocytic stomata in the upper epidermis of rosemary plantlets grown under in vitro conditions a) MS I b) MS II

Regarding stomatal distribution, the present data are supported by other reports in the literature (Munné-Bosch et al., 1999; Ullah et al., 2013). Such distribution is considered as ecological adaption to prevent the significant loss of water from leaves during hot and dry days. However, depending on natural growth conditions, in many habitat types can be found rosemary plants which have amphistomatic leaves due to high air humidity (Mbagwu et al., 2008). Differences in stomata distribution relate not principally to the culture conditions but also to the nutrient content. Such results are reasonable given that in vitro plantlets grow in high air humidity conditions, while during in vivo growth conditions the rates of transpiration are high (Kozai and Smith, 1995,

\section{Pospisilova et al., 1999).}

Another parameter monitored in the upper leaf epidermis for in vitro plantlets is stomatal density in both hormonal treatments during in vitro culture. From the results it could be noticed a considerable difference in this parameter between plants grown in MS I and the ones grown in MS II. Stomatal density increases considerably with the increase of BAP concentration in the nutrient media (Tab $1)$.
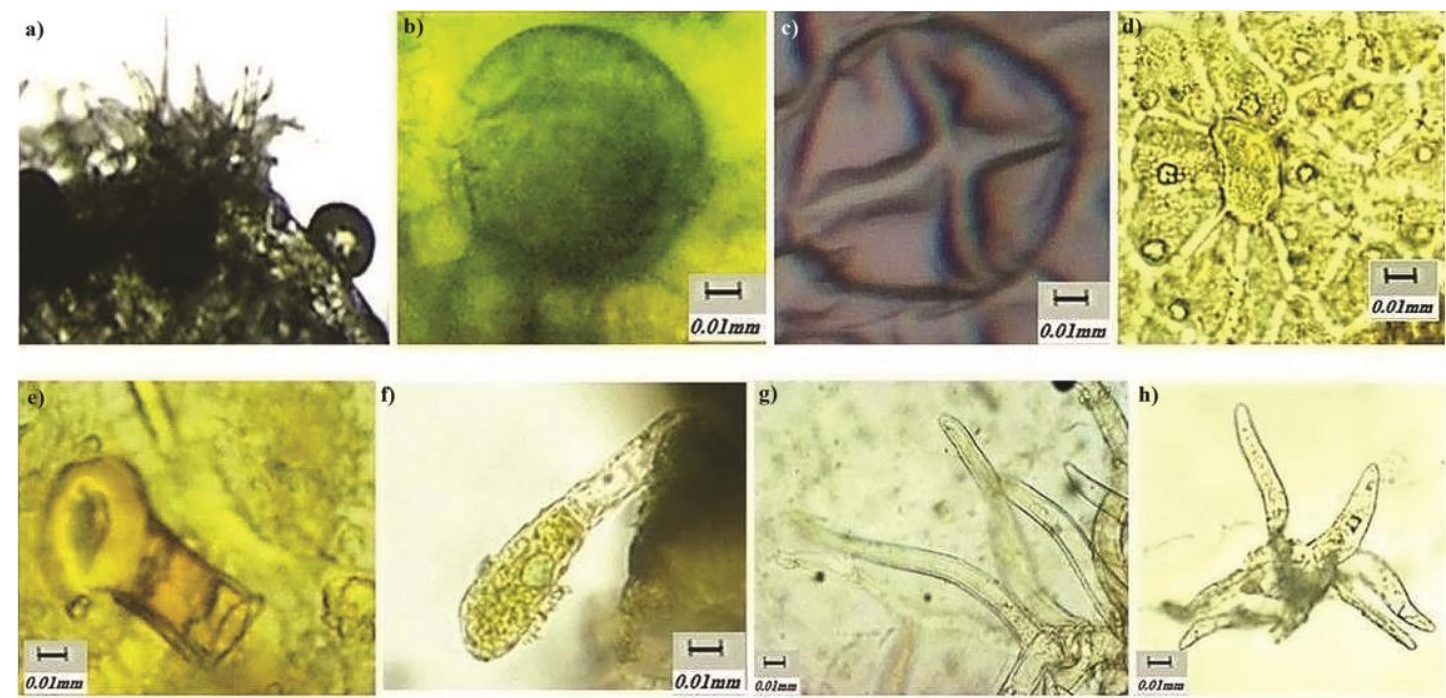

Figure 2 Types of trichomes observed in Rosmarinus officinalis L. plants under in vivo and in vitro conditions: a) stereomicroscopic view of peltate and non-glandular trichomes b) Peltate trichome c) peltate trichome with with four-celled head d) peltate trichome with 8 basal cells and presence of oxalate crystals e) capitate trichomes with two-celled head and bicellular stalk f) capitate trichomes with single-celled head and a bicellular stalk g, h) non-glandular furcate trichomes 
Table 2 Evaluation of stomata and glandular trichomes in the upper leaf epidermis for the three categories under study

\begin{tabular}{|c|c|c|c|}
\hline & $\begin{array}{c}\text { Glandular trichomes } \\
\text { density/microscopic } \\
\text { field (10x) }\end{array}$ & $\begin{array}{c}\text { Glandular } \\
\text { trichomes } \\
\text { density } / \mathrm{mm}^{2}\end{array}$ & $\begin{array}{c}\text { Glandular } \\
\text { trichomes } \\
\text { diameter } \\
(10 x)(\mu \mathrm{m})\end{array}$ \\
\hline In vivo & $77.90 \pm 1.32 \mathbf{A}$ & 28 & $\begin{array}{c}28.63 \pm 0.21 \\
\mathbf{A}\end{array}$ \\
\hline $\begin{array}{l}\text { In vitro MS } \\
\text { I }\end{array}$ & $203.68 \pm 8.69 \mathbf{B}$ & 74.47 & $\begin{array}{c}13.31 \pm 0.42 \\
\text { B }\end{array}$ \\
\hline $\begin{array}{l}\text { In vitroMS } \\
\text { II }\end{array}$ & $218.08 \pm 7.75 \mathbf{B}$ & 79.75 & $\begin{array}{c}14.07 \pm 0.35 \\
\text { B }\end{array}$ \\
\hline
\end{tabular}

Note: The values not connected by the same letter are very different between them

As noted by the results, the culture conditions have a considerable influence on both diameter and density of glandular trichomes. In vitro grown plantlets show a

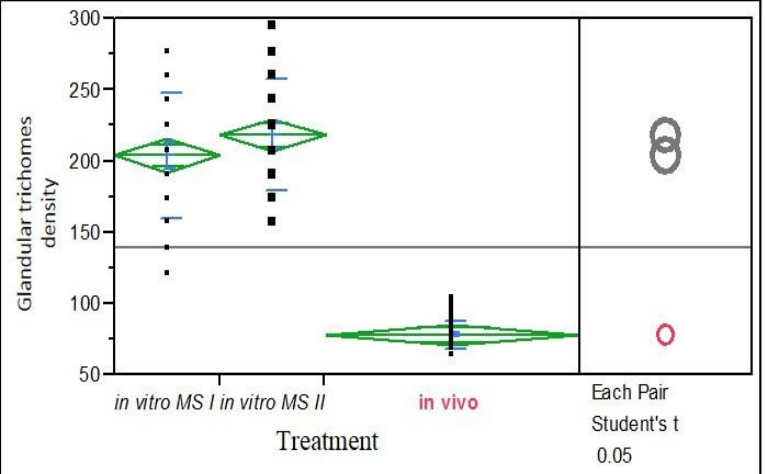

Figure 3 Oneway analysis for the three categories under study

Many studies have demonstrated differences in the density of trichomes or in the quantity of essential oils they contain by comparing in vivo plants with in vitro ones. Farooqi and Shukla (1990) point to the fact that growth regulators and/or plant hormones stimulate plant growth and biosynthesis of terpenes in a considerable number of aromatic-medicinal species, resulting in beneficial quality changes and quantity.

According to the reports of Vantu and Gales (2009) the density of the oily glands was greater both in the upper and lower epidermis of Chrysanthemum morifolium Ramat. Analysis of essential oils of Curcuma longa L. (Kuanar et al., 2009), Valeriana officinalis L. (Tousi et al., 2010), Valeriana glechomifolia Meyer (Salles et al., 2002), Valeriana edulis ssp. Procera (Castillo et al., 2002), Salvia officinalis L. (Avato et al., 2005) propagated in vitro show an increase in their quantity and quality compared to those grown in vivo.

Somaclonal variations of a specific type can be extremely important in improving certain plant lines (Jain, 2001). This trend is being used more and more today, especially in the use of tissue culture for the production of secondary metabolites. Thus, in vitro culture stress can cause constructive and destructive processes, and it is not only a selection factor but also a driving force to improve ecological adaptation processes (Gaspar et al., 2002)

\section{CONCLUSION}

Increased concentration of cytokinins in the nutrient medium induces morphological and physiological changes in leaf epidermis characters. The density of stomata increases significantly with the increase of BAP concentration in the nutrient media. In vitro grown plantlets show a density of glandular trichomes three times higher and a diameter two times lower than in vivo plantlets and these parameters increase in higher concentrations of BAP. It can be reasonably concluded that altering in vitro physical and/or chemical growth factors led to effective changes in epidermal characters responsible for secondary metabolites production. There are needed further studies to carefully analyse if fundamental changes in diameter and density of glandular trichomes affect positively or not the quality and/or quantity of essential oils.

\section{REFERENCES}

AVATO, I.M., FORTUNATO, I.M., RUTA, C., D’ELIA, R. 2005. Glandular hairs and essential oils in micropropagated plants of Salvia officinalis L. Plant Science, 169, 29-36. http://doi:10.1016/j.plantsci.2005.02.004

CASTILlO, P., ZAMILPA, A., MARQUEZ, J., HERNANDEZ, G., LARA, M. ALVAREZ, L. 2002. Comparative study of differentiation levels and valepotriate content of in vitro cultures and regenerated and wild plants of Valeriana edulis ssp. Procera. Journal of Natural Products, 65, 573-575. density of glandular trichomes three times higher and a diameter two times lower than in vivo plantlets. The obtained results suggest that a fundamental reason causing these changes is the presence of exogenous cytokinines in the nutrient medium during in vitro cultivation.

Presence and accumulation of essential oils are associated with the presence of specialized structures such as oil glands, secretory cavities, etc. According to Gottlieb and Salatino (1987) the production of essential oils and the formation of secretory structures are two processes closely related to one another. Consequently, secondary metabolites production is highly influenced by endogenous factors (stage of parent plant development or any specific organ, etc.), as well as by exogenous factors (biotic and abiotic) (Sangwan $\boldsymbol{e t}$ al., 2001; Lima et al., 2003; Gobbo-Neto and Lopes, 2007). These reports show that photosynthesis, photoperiod, light quality, climatic and seasonal changes, nutrition, humidity, salinity, temperature, growth regulators, and so on, are factors that affect the production of essential oils, both quantitatively and quantitatively.

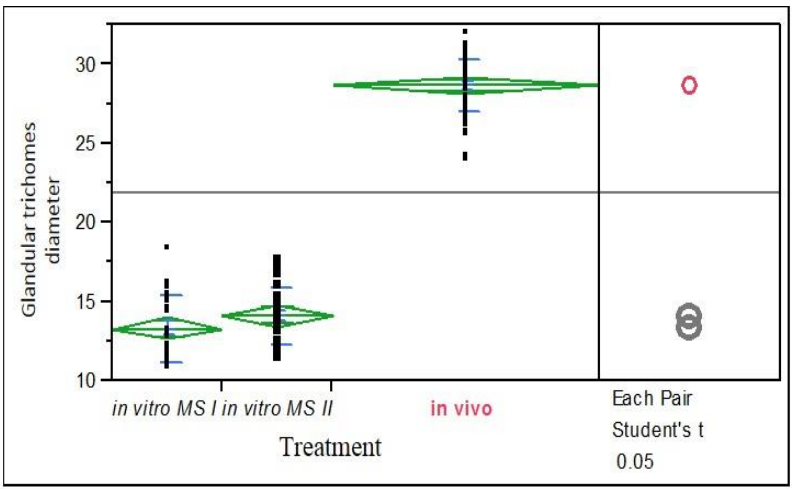

DILCHER, D.L. 1974. Approaches to the identification of angiosperm leaf remains. Botanical Review, 40, 1-157. http://doi:10.1007/BF02860067

FARBER, M., ATTIA, Z., WEISS, D. 2016. Cytokinin activity increases stomatal density and transpiration rate in tomato. Journal of Experimental Botany, 67(22), 6351-6362. http://doi:10.1093/jxb/erw398

FAROOQI, A.H.A., SHUKLA, A. 1990. Utilization of plant growth regulators in aromatic plant production. Chromatography, 12, 152-157.

GASPAR, T., FRANCK, T., BISBIS, B., KEVERS, C., JOUVE, L., HAUSMAN, J.F., DOMMES, J. 2002. Concepts in plant stressphysiology. Application to plant tissue cultures. Plant Growth Regulation, 37, 263-285.

GOBBO-NETO, L., LOPES, N.P. 2007. Medicinal plants: factors of influence on the content of secondary metabolites. Quim Nova, 30(2), 374-381. https://doi.org/10.1590/S0100-40422007000200026

GOTTLIEB, O.R., SALATINO, A. 1987. Função e evolução de óleos essenciais e de suas estruturas secretoras. Ciênc Cult, 39(8), 707-716. 1987.

HAZARIKA, B.N. 2006. Morpho-physiological disorders in in vitro culture of

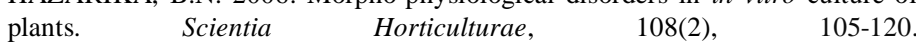
http://dx.doi.org/10.1016/j.scienta.2006.01.038

JAIN, S.M. 2001. Tissue culture-derived variation in crop improvement Euphytica, 118, 153-166.

KEVERS, C., FRANCK, T., STRASSER, R.J, DOMMES, J., GASPAR, T. 2004. Hyperhydricity of micropropagated shoots: a typicallystress-induced change of physiological state. Plant Cell Tissue and Organ Culture, 77, 141-150. KOZAI, T., SMITH, M.A.L. 1995. Environmental control in plant tissue culture - general introduction and overview. In: Aitken-Christie J, Kozai T, Smith MAL (Eds), Automation and Environmental control in plant tissue culture. Kluwer Academic Publishers, London, pp. 301 - 318, ISBN: 978-94-015-8461-6.

KUANAR, A., MOHANTY, S., PANDA, M.K, NAYAK, S. 2009. Essential oils from leaves of micropropagated turmeric. Current Science, 96(9), 2009.

LIMA, H.R.P., KAPLAN, M.A.C., CRUZ, A.V.M. 2003. Influence of abiotic factors on terpenoids production and variability in the plants. Floresta ambient, 10(2), 71-77.

MBAGWU, F.N., NWUACHUKWU, C.U., OKORO, O.O. 2008. Comparative leaf epidermal studies on Solanum macrocarpum and Solanum nigrum. Research Journal of Botany, 3 (1): 45-48, http://doi:10.3923/rjb.2008.45.48

MILLER, C.O., SKOOG, F., OKOMURA, F.S., SALTZA, M.H., STRONG, F.M. 1956. Isolation, structure and synthesis of kinetin, a substance promoting cell division. Journal of the American Chemical Society, 78, 1375-1380.

MUNNÉ-BOSCH, S., NOGUÉS, S., ALEGRE, L. 1999. Diurnal variations of photosynthesis and dew adsorption by leaves in two evergreen shrubs growing in Mediterranean field conditions. New Phytologyst, 144, 109-119.

MURASHIGE, T., SKOOG, F. 1962. A revised medium for rapid growth and bioassays with tobacco tissue cultures. Physiology Plantarum, 15, 473 - 497. 
NIR, I., MOSHELION, M., WEISS, D. 2014. The Arabidopsis Gibberellin Methyl Transferase 1 suppresses gibberellin activity, reduces whole-plant transpiration and promotes drought tolerance in transgenic tomato. Plant, Cell and Environment, 37, 113-123, http://doi:10.1111/pce.12135

OSAKABE, Y., OSAKABE, K., SHINOZAKI, K., TRAN, L.S.P. 2014. Response of plants to water stress. Plant Science, 5, 1-8.

POSPÍŠILOVÁ, J., TICHÁ, I., KADLEČEK, P., HAISEL, D., PLZÁKOVÁ, Š

1999. Acclimatization of micropropagated plants to ex vitro conditions. Biologia Plantarum, 42(4), 481-497.

ROBERTS, A., SMITH, E.F., HORAN, I., WALKER, S., MATHEWS, D. MOTTLEY, J. 1994. Stage III techniques for improving water relations and autotrophy in micropropagated plants. In: Lumsden, PJ, Nicholas JR, Davies WJ (Eds.) Physiology, Growth and Development of Plants in Culture. Kluwer Academic Publishers, pp. 314-321

SALLES, L.A., SILVA, A.L., FETT-NETO, A.G., POSER, G.L., RECH, S.B. 2002. Valeriana glechomifolia: in vitro propagation and production of valepotriates. Plant Science, 163, 165-168.

SANGWAN, N.S., FAROOQI, A.H.A., SHABIH, F., SANGWAN, R.S. 2001 Regulation of essential oil production in plants. Plant Growth Regulators, 34, 03 21.

SCHALlER, G.E., STREET, I.H., KIEBER, J.J. 2014. Cytokinin and the cell cycle. Current Opinion in Plant Biology, 21, 7-15.

SOUKUP, A., MALÁ, J., HRUBCOVÁ, M., KÁLAL, J., VOTRUBOVÁ, O., CVIKROVÁ, M. 2004. Differences in anatomical structure and lignin content of roots of pedunculate oak and wild cherry-tree plantlets during acclimation. Biologia Plantarum, 48(4), 481-489.

TOUSI, S.E., RADJABIAN, T., EBRAHIMZADEH, H., NIKNAM, V. 2010.

Enhanced production of valerenic acids and valepotriates by in vitro cultures of Valeriana officinalis L. International Journal of Plant Production, 4(3), 1735 6814.

ULlAH, S., IBRAR, M., BARKATUllAH, M., ROOHULlAH, N. 2013. Pharmacognostic, larvicidal and phytotoxic profile of Coleus forskohlii and Rosmarinus officinalis. Journal of Pharmacognosy and Phytotherapy, 5(4), 5963.

VALLVERDÚ-QUERALT, A, REGUEIRO, J, MARTÍNEZ-HUÉLAMO, $\mathrm{M}$, RINALDI ALVARENGA, J.F., LEAL, L.N., LAMUELA-RAVENTOS, R.M 2014. A comprehensive study on the phenolic profile of widely used culinary herbs and spices: Rosemary, thyme, oregano, cinnamon, cumin and bay. Food Chemistry, 154, 299-307. http://doi:10.1016/j.foodchem.2013.12.106

VANTU, S., GALES, R.C. 2009. Structural characteristics of Chrysanthemum morifolium Ramat (Romica cultivar) regenerated in vitro. Analele Științifice ale Universității 'Al I Cuza' din Iași, 10(2), 43-50.

WILKINSON, H.P. 1979. The Plant Surface (Mainly Leaf). In: Metcalfe, C.R and Chalk, L., Eds., Anatomy of the Dicotyledons, 2nd Edition, Clarendon Press, Oxford, 97-167. 